\title{
CONCEPTUAL SPHERE OF MEDIA DISCOURSE OF MATERNITY IN RUSSIAN AND DANISH PRINT MASS MEDIA
}

\author{
Anna A. Kuvychko \\ Pushkin State Russian Language Institute, Moscow, Russia \\ Albertina G. Chafonova \\ Pushkin State Russian Language Institute, Moscow, Russia \\ Vera V. Boguslavskaya \\ Pushkin State Russian Language Institute, Moscow, Russia
}

\begin{abstract}
The results of linguoculturological analysis of the Russian and the Danish web-based media texts are described in the paper. The cultural and linguistic specifics of the representation of conceptual sphere of maternity media discourse - a fragment of the national conceptosphere composed of concepts as structural units - are considered. The research relevance is determined by the intense interest of modern scholars to the sociocultural content of the maternity phenomenon, as well as to the issue of the representation of the concept mother as one of the key cultural concepts in linguistic studies of various types. Comparative reference to the linguistic and linguoculturological representation of the key concepts of the Russian and Danish discourse of maternity Mother / Mum (Moder / Mor) and Woman (Kvinde) allows making definite conclusions on the existence of their cultural and linguistic implementation features. This is due to both sociocultural and ethnopsychological factors: the predominance of interest in personal problems of women as part of the society in Danish media texts, and leveling the value of the personal in favor of the public and the national in the image of woman-mother produced in the Russian media texts; as well as interest to the maternity phenomenon as an opportunity for the social and personal development of woman in the Danish media discourse, and the prevalence of interest in the social aspects related to motherhood - in the Russian media discourse.

Key words: media discourse of maternity, national conceptual sphere, national and cultural specifics, linguistic representation, linguoculturological analysis.

Citation. Kuvychko A.A., Chafonova A.G., Boguslavskaya V.V. Conceptual Sphere of Media Discourse of Maternity in Russian and Danish Print Mass Media. Vestnik Volgogradskogo gosudarstvennogo universiteta. Seriya 2, Yazykoznanie [Science Journal of Volgograd State University. Linguistics], 2018, vol. 17, no. 4, pp. 135-145. (in Russian). DOI: https://doi.org/10.15688/jvolsu2.2018.4.12

\section{КОНЦЕПТОСФЕРА МЕДИАДИСКУРСА МАТЕРИНСТВА В РОССИЙСКИХ И ДАТСКИХ ПЕЧАТНЫХ СМИ}

\author{
Анна Александровна Кувычко \\ Государственный институт русского языка им. А.С. Пушкина, г. Москва, Россия \\ Альбертина Германовна Чафонова \\ Государственный институт русского языка им. А.С. Пушкина, г. Москва, Россия \\ Вера Васильевна Богуславская \\ Государственный институт русского языка им. А.С. Пушкина, г. Москва, Россия
}


Аннотация. Исследование находится в русле актуальных проблем лингвистики, связанных с выявлением универсального и особенного в содержании ключевых концептов европейских культур, а также с определением причин, которые обусловливают различия в смысловом наполнении таких концептов. В статье представлены результаты лингвокультурологического анализа публикаций российских и датских печатных и интернет-изданий: выявлены национально-культурные особенности лингвистической репрезентации концептосферы медиадискурса материнства - фрагмента национальных концептосфер, состоящих из концептов как структурных единиц. Сопоставительный анализ лингвистической и лингвокультурологической репрезентации ключевых концептов российского и датского дискурса материнства - Мать / Мама (Moder / Mor) и Женщина (Kvinde) - позволил установить, что национально-культурные особенности их реализации обусловлены как социокультурными, так и этнопсихологическими факторами: преобладанием интереса к личностным проблемам женщины как части социума в датских медиатекстах и нивелированием значения личностного в пользу общественного, общенационального и общегосударственного в образе женщины-матери, созданном в российских медиатекстах, а также интересом к феномену материнства как возможности социального и личностного развития женщины в датском медиадискурсе и превалированием интереса к связанным с материнством социально-бытовым вопросам - в российском.

Ключевые слова: медиадискурс материнства, национальная концептосфера, национально-культурные черты, лингвистическая репрезентация, лингвокультурологический анализ.

Цитирование. Кувычко А. А., Чафонова А. Г., Богуславская В.В. Концептосфера медиадискурса материнства в российских и датских печатных СМИ // Вестник Волгоградского государственного университета. Серия 2, Языкознание. - 2018. - Т. 17, № 4. - C. 135-145. - DOI: https://doi.org/10.15688/jvolsu2.2018.4.12

\section{Введение}

Материнство - сложный, аксиологически отмеченный феномен, тесно связанный с духовно-нравственными основами жизни человека. В современных массмедиа тема материнства характеризуется неоднородностью и многоплановостью. Медиадискурс материнства, как любой массмедийный дискурс, чувствителен к условиям актуального социального бытия, контексту происходящих событий, остро реагирует на доминирующую идеологическую направленность, и, являясь своеобразным зеркалом реального мира, в то же время сам создает параллельную картину мира, обусловленную запросами современного общества.

Межкультурное исследование дискурса материнства позволяет увидеть глубинные национально-культурные установки, которые вне сопоставительного контекста не являются очевидными. Рассмотрение особенностей медиадискурса материнства на основе анализа статей российских и датских изданий направлено на поиск тех его компонентов, которые меняют свой статус с социального на национально-культурный.

Представленное в настоящей статье исследование дискурса материнства направлено на обнаружение устойчивого, сформированного в общественном сознании и отраженно- го в текстах массмедийных источников «набора» образов, репрезентирующих концептосферу медиадискурса материнства как продукт когнитивной деятельности современного российского и датского социума. Одним из ключевых терминов исследования является «концепт», который трактуется в лингвистической концептологии как обозначение моделируемой лингвистическими средствами единицы национального когнитивного сознания, единицы моделирования и описания национальной концептосферы [Попова, Стернин, 2007, с. 36]. Под концептосферой медиадискурса материнства мы понимаем фрагмент национальной концептосферы, составленный из концептов как его единиц и отражающий определенную область функционирования языка, а именно - тексты СМИ, репрезентующие дискурс материнства.

Актуальность работы и ее ценность определяются, с одной стороны, значительным интересом современных ученых к социокультурному содержанию феномена материнства [Васягина, 2013; Сасункевич, 2009; Шпаковская, 2014; Юсупова, 2000], наличием масштабных социологических исследований вопросов семьи и брака на материале текстов СМИ [Свитич, 2015], исследований феномена материнства в русле теории деятельности [Матвеева, 2004] и современных цифровых медиатехнологий в межличностной коммуникации [Vaillancourt, 2015]. 
Кроме того, повышенное внимание языковедов привлечено к вопросу репрезентации концепта «мать» как одного их ключевых концептов культуры в сопоставительных лингвистических исследованиях (см., например: [Андреянова, 2011; Андреянова, Багаутдинова, 2011; Ани Рахмат, 2012; Перевалова, 2016]), а также в работах, касающихся объективации указанного концепта в текстах художественной литературы и публицистики разного времени [Атрощенко, 2014; Дякиева, Омакаева, 2012; Карелова, 2008]. С другой стороны, выбор в качестве материала изучения медиадискурса материнства современных медиатекстов позволяет эксплицировать полученные результаты в русле актуальных социальнокультурных тенденций, присущих современным российскому и датскому обществам. Представляемое исследование ставит одной из своих целей выйти за рамки рассмотрения материнства как социально-культурного феномена в область лингвистической репрезентации его национально-культурных особенностей.

Концептосфера медиадискурса материнства - это набор тематических кластеров, сгруппированных вокруг ключевых, смыслообразующих концептов Мать, Женщина и Ребенок, поэтому для изучения особенностей российского и датского медиадискурсов материнства необходимо было выявить, как актуализируются в текстах российских и датских СМИ указанные концепты.

Материал для изучения определялся методом сплошной выборки, проведенной с использованием контент-анализа статей в датских изданиях «Berlingske» (с 2016 по 2017 гг.) и «Dansk Kvindesamfund» (с 2012 по 2014 гг.), а также статей в «Российской газете» и публикаций, размещенных на интернет-портале «Вести.ру» (с 2008 по 2018 гг.). Для дальнейшего рассмотрения были выявлены те статьи, в которых отмечены лексические единицы материнство (moderskab) и/или мать (moder).

Базовый метод исследования - лингвокультурологический анализ, основанный на приеме текстовой интерпретации. Для более подробного лингвокультурологического интерпретационного (прагматического) анализа были выбраны статьи, наиболее отражающие исследуемую тему: “Jeg elsker ikke at være mor” («Мне не нравится быть мамой») (Berlingske, 29.09.2016) и "Hvad er en 'rigtig' mor egentlig?" («Что такое “настоящая” мама?») (Berlingske, 28.09.2016), «Анна Кузнецова: у материнства особая миссия» (Вести.ру, 2018), «В Липецке стартовала акция “Материнская слава"» (Вести.ру, 2017), «Счастье быть мамой: Россия отмечает День матери» (Вести.ру, 2016), «Мама-карьеристка. Дети или работа - неправильный выбор?» (Российская газета, 2013).

\section{Особенности медиадискурса материнства в России и Дании}

Прежде чем перейти к непосредственному описанию лингвокультурологической репрезентации ключевых концептов медиадискурса материнства в российских и датских СМИ, обозначим некоторые важные, на наш взгляд, национально-культурные особенности медиадискурса материнства в России и Дании.

Первичный анализ выбранного медиаматериала показал, что датские СМИ акцентируют внимание на современных проблемах материнства, рассматривая их как личные проблемы женщин-матерей и классифицируя их по определенным параметрам. Героинями датского дискурса становятся «молодые матери» (unge mødre), «одинокие матери» (enlige mødre), «карьерные матери» (karrieremødre) (более привычный перевод «матери-карьеристки» может быть воспринят негативно), «зрелые матери» (modne mødre) и т. д. Тема семьи, которая в российских СМИ практически неразрывно связана с материнством, в датских СМИ лишь иногда связана с материнством и никогда не доминирует, уступая место темам «личностным», «частным», а именно: психологическое и физическое состояние женщины-матери вообще или какой-то конкретной женщины, история которой рассказывается в качестве примера.

Типичными для датского дискурса материнства являются такие идеи: «вместо того, чтобы развивать самооценку женщины, материнство разрушает ее»-moderskab i stedet for at udvikle kvindens selvvord, er det, der bryder hende ned (DK), «сегодня многие женщины переживают, что материнство несовме- 
стимо с требованиями, которые они предъявляют к самостоятельной жизни» - mange kvinder oplever $i$ dag, at moderskabet er uforeneligt med de krav, de stiller til et selvstoendigt liv (DDO).

Объяснение указанных особенностей можно найти в этнопсихологических характеристиках датской культуры как культуры западноевропейской, основанной на примате частного над коллективным. Русская культу$\mathrm{pa}$, напротив, тяготеет к коллективному, к общему и даже всеобщему, что отражается в том числе в дискурсе материнства в российских СМИ. Присущая русской культуре сакрализация материнства (например, существует всероссийская программа под названием «Святость материнства») исключает возможность рассмотрения данного дискурса лишь как «дискурса о матерях и для матерей», но обусловливает необходимость расширить его границы вплоть до общекультурного масштаба. Таким образом, русский дискурс материнства становится одновременно дискурсом, в котором эксплицируется тема важности роли матери, семьи, государства, русской культуры. Например, типичным является следующий прецедентный заголовок газетной статьи: «Мама может. Когда в России войдут в моду многодетные семьи?» (Российская газета, 2017).

В датском медиадискурсе отчетливо прослеживается мысль о том, что сегодняшняя мать в Дании не может найти «золотой середины» в том, должна ли она после рождения ребенка полностью посвятить себя его воспитанию или же она должна продолжать свою карьеру. Оба из указанных путей в действительности представляют собой крайности, которые общественное мнение воспринимает негативно. В статье «Jeg elsker ikke at være mor» («Мне не нравится быть матерью») (Berlingske, 29.09.2016) читателю рассказана история двух женщин-матерей, каждая из которых оказалась под давлением общественной критики за выбранный ею «способ быть матерью»: De møder kritik for deres måde at vare mor på. Та мать, которая предпочла продолжить карьеру, оставив детей на попечение мужа, столкнулась с упреками в безответственном отношении к воспитанию детей, а та, которая все свое время посвятила ребен- ку, - в несоответствии современным нормам и запросам социума.

Тема «карьера или/и материнство» затрагивается и в российских изданиях. Например, автор статьи «Мама-карьеристка. Дети или работа - неправильный выбор?» (Российская газета, 2013) ставит своей целью охарактеризовать возможности и желание современных российских женщин совмещать карьеру с воспитанием детей. Представленные в статье мнения женщин по данному вопросу указывают на сложность такого совмещения, при этом проводится четкая дифференциация карьеры и работы, когда карьера является практически недостижимой роскошью, а работа - необходимостью.

Медиадискурс создает особую картину мира, в которой материнство редко представлено в «позитивном контексте». Темой рассмотрения в российских СМИ часто становятся связанные с материнством проблемы сугубо бытового характера (материальное обеспечение, жилищный вопрос, медицинская помощь). На фоне такого подхода к освещению феномена материнства в печатных СМИ особую значимость приобретают приведенные в тексте уже упомянутой статьи «Мама может. Когда в России войдут в моду многодетные семьи?» (Российская газета, $2017)$ слова уполномоченного при президенте по правам ребенка А. Кузнецовой, которая говорит о поддержке ценностей семьи, материнства, отцовства и обращает внимание на то, что «в современном информационном пространстве очень не хватает простых и добрых историй о семье и семейном счастье».

Итак, в медиадискурсе материнства в России и Дании можно обозначить следующие особенности или тенденции: 1) преобладание интереса к личностным проблемам женщины как части социума в датских медиатекстах и нивелирование значения личностного в образе женщины-матери в пользу общественного, общенационального и общегосударственного - в российских; 2) интерес к феномену материнства как возможности социального и личностного развития женщины в датском медиадискурсе; превалирование интереса к связанным с материнством социально-бытовым вопросам - в российском. 
Указанные особенности представляются значимыми для настоящего исследования ввиду их национально- и социально-культурной обусловленности, а также позволяют глубже проникнуть в концептосферы рассматриваемого дискурса.

\section{Ключевые концепты медиадискурса материнства в российских и датских печатных СМИ}

К ключевым концептам российского и датского медиадискурсов материнства относятся концепты Мать / Мама (Moder / Mor) и Женщина (Kvinde), кроме того, концептосферу медиадискурса материнства формируют и концепты Ребенок (Barn), Семья (Familie), Отец / Папа (Far), но при этом они являются в некотором смысле тематическими, так как высвечивают определенные стороны ключевых концептов. Концепты Мать и Женщина, равно как Mor и Kvinde, всегда сосуществуют в текстах медиадискурса и обнаруживают взаимоопосредованность.

В датском дискурсе концепт Moder / Mor (Мать / Мама) часто реализуется в признаке «одна из ролей женщины»: mor - en rolle, hun ikke elsker («мама - это роль, которая ей не нравится»); hun ser kritisk på mor-rollen («она смотрит критически на роль мамы»); hun som en del af en generation af yngre mødre skal tvinges ned $i$ en mor-rolle («она, как часть поколения молодых матерей, должна быть принуждена к роли мамы»); kvinder er usikre $i$ rollen som mor («женщины не уверены в такой роли, как мама»); vi kvinder ger selv tilbage til en morrolle («мы, женщины, возвращаемся к роли мамы»); skal vi som mødre vore fuldt dedikeret til morrollen («как матери, мы должны быть полностью посвящены роли мамы»). Фактически в датском медиадискурсе материнства концепт Moder / Mor (Мать / Мама) никогда не превалирует над концептом Kvinde (Женщина), который оказывается главенствующим: de to unge kvinder er mødre på vidt forskellig vis («две молодые женщины являются разными матерями»); den 32-erige $k v i n d e s$ måde at vare mor på («способ тридцатидвухлетней женщины быть матерью»); det er en kvinde, der giver sig fuldstoendig hen til moderskabet («это женщина, которая все- цело отдает себя материнству»); det er kvinderne, der skal vare der 100 procent for børnene («это женщины, которые должны на сто процентов отдавать себя детям»).

Анализ датских статей показывает, что в центре дискурса материнства оказывается женщина-мать, или «женщина в роли матери», ей предъявляются требования, которым она должна соответствовать, однако зачастую эти требования противоречивы: Selvom mange $k v i n d e r$ har en karriere, sidder vi selv fast $i$ en traditionel opfattelse af, hvad en rigtig mor er («Несмотря на то, что у многих женщин есть карьера, мы придерживаемся традиционного представления о том, что такое настоящая мать»); Problemet er, at vi unge kvinder får at vide, at vi skal tage en uddannelse og vare innovative, men når vi får børn, skal vi rulle det hele tilbage igen og vare tilfredse med at vare mødre («Проблема заключается в том, что нам, молодым женщинам, говорят, что нам нужно быть образованными и инновационными, но когда у нас появляются дети, мы должны снова повернуть назад и довольствоваться только тем, что мы матери»); hun skal vaere den moderne kvinde, der hurtigt kommer tilbage til arbejdsmarkedet («она должна быть современной женщиной, которая быстро возвращается на рынок труда»).

В какой-то мере установка на то, что общество ждет от женщины определенного поведения, и подчеркивание этой идеи в репликах самих датских женщин, которые приводятся в анализируемых статьях, согласуются с одним из наиболее ярких выразителей датской национальной идентичности - «Законом Янте» («Janteloven»). Это своеобразный свод законов, которые сформулированы по модели $D u$ skal ikke...(«Ты не должен..»). Однако в медийном дискурсе появляется иная модель - vi skal («мы должны»). Сравним: vi unge kvinder får at vide, at vi skal tage en uddannelse og vare innovative, men når vi får børn, skal vi rulle det hele tilbage igen («нам, молодым женщинам, говорят, что нам нужно быть образованными и инновационными, но когда у нас появляются дети, мы должны снова повернуть назад»); politikerne vil gerne have, at vi kvinder tager på arbejde og får en karriere, men samtidig skal vi som mødre vare fuldt dedikeret til morrollen («политики хотят, 
чтобы мы, женщины, пошли на работу и сделали карьеру, но в то же время, как матери, мы должны быть полностью посвящены роли мамы»); vi har flere ting, vi skal leve op til end vores forceldre («в отличие от наших родителей, у нас больше вещей, которые мы должны делать»). В приведенных контекстах можно увидеть, что местоимение vi «мы» обозначает «датских женщин, которые уже или потенциально являются матерями». В дискурсе прослеживается устойчивая самоидентификация датских женщин, вступающих в некотором смысле в полемику со всем датским обществом, представленным прежде всего через политический сектор.

Таким образом, в датских СМИ показано, что женщина часто сталкивается с проблемой ее соответствия как матери определенным запросам датского общества и неким стандартам так называемой en "rigtig” mor («настоящей, правильной матери»), которые сложились в общественном коллективном сознании. Центральными концептами, эксплицированными в дискурсе, являются тесно связанные концепты Kvinde (Женщина) и Mor (Мать), при этом концепт Mor не превалирует над концептом Kvinde, так как в основном реализуется в признаке «одна из ролей женщины», при этом вопрос о том, ключевая ли это роль, становится дискуссионным.

Смыслообразующими концептами русского медиадискурса материнства также являются концепты «мать» и «женщина», однако именно концепт Мать выходит на первый план. В зависимости от характера новостей в медийных текстах можно встретить употребление как более официальной лексемы мать, так и разговорного варианта - мама, при этом очевидна тенденция к более частому использованию именно варианта мама.

В публикациях российских СМИ утверждается, что в российском обществе материнство представляется главной ипостасью женщины. На фоне рассмотренных датских статей, в которых центральной темой дискуссии становится поиск баланса между саморазвитием женщины (в том числе за счет карьерного роста) и ее ответственностью как матери за своего ребенка, контрастной является статья «В Липецке стартовала акция “Материнская слава"» (Вести.ру, 2017), рас- сказывающая об акции, призванной показать, что успешное материнство - это модно. Контраст заключается в том, что в данной публикации под «успешным материнством» подразумевается вовсе не найденный женщиной баланс между «собой» и «ребенком». В акции принимают участие многодетные мамы, чьи дети успешно справляются со школьной программой, занимаются в дополнительных секциях, учатся в вузе или уже работают. Таким образом, «успешное материнство» интерпретируется прежде всего как успешное воспитание детей. Это полностью согласуется с центральной идей, высказанной в другой статье: Услышать маму значит усльтшать будущее! (Вести.ру, 2018).

Примером, иллюстрирующим наши утверждения о том, что в российском медиадискурсе материнства концепт Мать более релевантен по сравнению с концептом Женщина, а также о том, что отмеченный выше баланс оказывается смещенным в сторону концепта Ребенок, является следующая трактовка содержания Дня Матери: Смысл праздника поддержать семейные устои и женщин, отдающих себя детям (Вести.ру, 2016).

Более того, уже обозначенная особенность отражения концепта Мать / Мама в датском медиадискурсе (Мама как «одна из ролей женщины») также имеет расхождения с тем, как реализуется указанный концепт в российских СМИ. Одна из выбранных для подробного анализа статей - «Мама-карьеристка. Дети или работа - неправильный выбор?» (Российская газета, 2013) - дает интересный материал для сопоставления, так как написана на схожую с проанализированными выше датскими публикациями тему. В центре внимания статьи - вопрос о том, совместимы ли материнство и карьерный рост. Как и датские материалы, статья в «Российской газете» построена на репликах и интервью женщин-матерей. Примечательно, что о выборе между карьерой и воспитанием ребенка фактически речи не идет, и большинство респонденток убеждены, что карьера и дети несовместимы: вариант (совмещения воспитания и карьеры $-A$. K., А. Ч., В. Б.) больше теоретический, потому что дети всегда остаются главной ответственностью женщины; утверждая, что «детям никто 
не заменит мать», россияне считают, что карьера и дети несовместимы; карьеру и детей совмещать можно, но где-то обязательно будут прокольл.

Уже отмеченная тесная взаимосвязь в российском медиадискурсе материнства концептов «мать» и «ребенок» находит свое эмпирическое подтверждение в исследовании А.В. Микляевой и П.В. Румянцевой [2018], целью которого было обнаружить имплицитный, малоосознаваемый пласт в представлениях о материнстве в современном интернет-дискурсе. Результаты указанного исследования показали, что наиболее частотной темой, в которой выявлены некоторые противоречия между «идеальными» представлениями о материнстве и их фактическим воплощением, оказалась тема взаимоотношений женщины-матери и ребенка в соотношении «мало внимания к ребенку - мало внимания к себе».

При анализе датских статей нами было обнаружено, что ответы женщин имплицитно указывали на существование некоего спора, полемического диалога между женщинамиматерями и обществом, в статье «Российской газеты» респондентки не выделяют себя в какую-либо группу и не относят себя к какой-либо категории, говоря о «женщинах вообще» или о «себе в частности» (мама пятилетней Вари и восьмилетней Маши Наталья Кульева... признается, что возможности думать о карьере у нее нет; я оставляла дочь с мамой и шла на репетицию или работу; если женщчина занимается своим бизнесом, найти время на ребенка очень непросто - бизнес требует максимальной отдачи; возможность совместить карьерный взлет с детьми зависит от самой женщины и ее окружения). Исключением является следующая реплика одной из респонденток, которая причисляет себя к «карьеристкам»: нам, современным карьеристкам, легче (чем было родителям в советское время - A. K., $A$. Ч., В. Б.).

Восприятие материнства как одной из ролей женщины (ср. в датских статьях: mor en rolle («мать - это роль»), mor-rollen («роль матери»), rollen som mor («такая роль, как мать») в российских СМИ не отражено, при этом появляются упоминания роли мамыдомоседки и роли мамы-карьеристки, ко- торые рассматриваются как две крайности в поведении женщины-матери. В датском дискурсе им соответствуют speltmoren (буквально «пшеничная мама», пренебрежительно о женщине, которая проводит много времени, заботясь о своих детях (DDO) и karrieremoren («карьерная мама»/ «мамакарьеристка»).

В российском медиадискурсе материнства имплицитно выражена идея о том, что мама может быть карьеристкой или домохозяйкой, но в первую очередь должна быть мамой: ведь в понимании материнства как одной из ролей женщины, а точнее в отказе от такого понимания, заключается ответ на вопрос о предназначении женщины - не исполнять «роль матери», но быть матерью.

\section{Выводы}

Представленное в статье исследование было направлено на обнаружение и описание особенностей репрезентации концептосфер дискурса материнства в текстах российских и датских печатных СМИ.

Для датского медиадискурса материнства существенными являются лингвистические репрезентации таких признаков ключевых концептов, как «mor-rollen» («роль матери») и «еn "rigtig” mor» («настоящая, правильная мать»). Обнаружены устойчивая тенденция к реализации концепта Mor (Мать) как «одной из ролей женщины» и попытка создания в датском медиадискурсе образа идеальной матери. С лингвистической точки зрения словосочетание en "rigtig” mor, которое может быть переведено как «правильная мама», отражает наличие определенных правил, которым должна следовать «настоящая (правильная) мать». Проведенный анализ датских медиатекстов подтвердил наличие такого подтекста в указанном словосочетании: в статьях, посвященных проблемам материнства, используется речевая модель vi skal («мы должны»), выражающая некий протест современных датских женщин-матерей.

Сопоставление способов лингвистической и лингвокультурологической объективации ключевых концептов дискурса материнства в российских и датских СМИ позволило сделать 
вывод о том, что концепты Мать / Мама (Moder / Mor) и Женщина (Kvinde) всегда сосуществуют в текстах медиадискурса. Однако если в датском медиадискурсе главенствующее положение занимает концепт Женщина (Kvinde), а концепт Мать / Мама (Moder / Mor) становится одной из его составляющих («мать как одна из ролей женщины»), то в российском медиадискурсе доминирует концепт Мать.

В российском медиадискурсе реализуется понимание материнства не просто как одной из ролей женщины, но как ее призвания, особой миссии, поэтому, когда женщина становится матерью, другой ее статус (женщина) отходит на второй план. В этом изменении заключается еще одна национальнокультурная особенность самого феномена материнства в России - жертвенность матери, ее самозабвенная отдача своей семье и своим детям.

Указанная особенность находит речевое воплощение в текстах российских СМИ: рядом с репрезентантами концепта Мать постоянно располагаются репрезентанты концептов Ребенок или Семья, что не характерно для датских текстов, в которых концепт Mor актуализируется более обособленно, а акцент переносится на социальную и личностную реализацию женщины «в роли матери».

Таким образом, взаимосвязанные концепты Мать / Мама (Moder / Mor) и Женщина (Kvinde), несмотря на общую для российского и датского дискурсов материнства тенденцию к их нераздельному представлению, не являются равноценными (характерно для датского медиадискурса превалирование концепта Kvinde, для российского медиадискурса - превалирование концепта Мать).

Резюмируя вышесказанное, следует подчеркнуть, что лингвокультурологическая сопоставительная интерпретация текстов российских и датских печатных СМИ дает возможность обнаружить существующие национально-культурные особенности репрезентации концептосфер дискурса материнства и позволяет выявить реализацию социокультурно обусловленных закономерностей когнитивной деятельности современного российского и датского социума.

\section{СПИСОК ЛИТЕРАТУРЫ}

Андреянова М. А., 2011. Концепт 'мать (mere)' и средства его реализации во французском и русском языках (на материале романов Э. Золя и Л.Н. Толстого) // Вестник Челябинского государственного университета. № 28 (243). С. 13-16.

Андреянова М. А., Багаутдинова Г. А., 2011. Реализация концепта 'мать (mother)' в русском и английском языках (на материале романов М. Горького и Дж. Э. Стейнбека) // Вестник Челябинского государственного университета. № 17 (232). C. 17-22.

Ани Рахмат, 2012. Вербализация концепта мать в русской фразеологии (на фоне индонезийского языка) // Известия Российского государственного педагогического университета им. А.И. Герцена. № 152. С. 101-105.

Атрощенко Е. О., 2014. Функционирование концепта «Мать» в русской художественной прозе XIX века // Научный журнал Кубанского государственного аграрного университета. № 97. C. 1-12.

Васягина Н. Н., 2013. Субъектное становление матери в современном социокультурном пространстве России : монография. Екатеринбург : [б. и.]. $364 \mathrm{c.}$

Дякиева Б. Б., Омакаева Э. У., 2012. Образ матери в калмыцком фольклоре: к проблеме универсального и специфического (на материале фольклорный текстов) // Вестник Калмыцкого института гуманитарных исследований. № 2. С. $183-187$.

Карелова И. И., 2008. Концепт «Мать» в идиоконцептосфере Л.Е. Улицкой // Известия Волгоградского государственного педагогического университета. № 10. С. 18-21.

Матвеева Е. В., 2004. Анализ материнства с позиции теории деятельности. Киев : ВГГУ. 326 с.

Микляева А. В., Румянцева П. В., 2018. «\#Онажемать»: имплицитные социальные представления о материнстве в современном российском интернет-дискурсе // Женщина в российском обществе. № 1 (86). С. 67-77.

Перевалова С. Г., 2016. Вербализация концепта «Мать» через пословично-поговорный и фразеологический фонды русского языка (на фоне французского языка) // Научный вестник Воронежского государственного архитектурно-строительного университета. Серия: Лингвистика и межкультурная коммуникация. № 2 (21). С. 135-139.

Попова 3. Д., Стернин И. А., 2007. Когнитивная лингвистика. М. : АСТ : Восток-Запад, 2007. 314 с.

Сасункевич О. М., 2009. Медикализация дискурса о материнстве в белорусских медиа // Журнал 
исследований социальной политики. Т. 7, № 3. С. $405-418$.

Свитич Л. Г., 2015. Семья и будущее России. Социологическое исследование: контент-анализ конкурсных публикаций. М. : Фак. журналистики МГУ. 154 с.

Шпаковская Л. Л., 2014. Дискурсивное производство социального неравенства материнства // Женщина в российском обществе. № 2 (71). C. 77-85.

Юсупова О. Г., 2000. Социальный смысл материнства в современной России: («Ваш ребенок нужен только Вам») // Социологические исследования. № 11. С. 98-107.

Vaillancourt Melissa A., 2015. Mediated Motherhood: Discourse and Maternal Identity in the Digital Age. Dissertations - ALL. Paper 357. Syracuse University. URL: https://surface.syr.edu/cgi/ viewcontent.cgi?referer=https:/www.google.ru/ \&httpsredir $=1 \&$ article $=1357 \&$ context $=$ etd $($ date of access: 25.03.2018).

\section{ИСТОЧНИКИ И СЛОВАРИ}

Becmu.py, 2016-«Счастье быть мамой: Россия отмечает День матери» // Вести.ру. 2016. URL: https://www.vesti.ru/doc.html?id=2826437 (дата обращения: 15.06.2018).

Becmu.py, 2017 - «В Липецке стартовала акция “Материнская слава"» // Вести.py. 2017. URL: https://www.vesti.ru/doc.html?id=2929087 (дата обращения: 15.06.2018).

Becти.py, 2018 - «Анна Кузнецова: у материнства особая миссия» // Вести.py. 2018. URL: https:// www.vesti.ru/doc.html?id=2993884 (дата обращения: 15.06.2018).

Российская газета, 2013 - «Мама-карьеристка. Дети или работа - неправильный выбор?» // Российская газета. 2013. № 220. URL: https:// rg.ru/2013/10/02/kariera.htm (дата обращения: 15.06.2018).

Российская газета, 2017 - «Мама может. Когда в России войдут в моду многодетные семьи?» // Российская газета. 2017. № 273. URL: https:// rg.ru/2017/11/30/kogda-v-rossii-vojdut-v-modumnogodetnye-semi.html (дата обращения: 05.06.2018).

Berlingske, 28.09.2016 - «Hvad er en "rigtig" mor egentlig?»// Berlingske. 28. September 2016. URL: "Berlingske" https://www.b.dk/nationalt/ hvad-er-en-rigtig-mor-egentlig (date of access: 15.06.2018).

Berlingske, 29.09 2016 - "Jeg elsker ikke at være mor" // Berlingske. 29. September 2016. URL: "Berlingske" https://www.b.dk/nationalt/hvad- er-en-rigtig-mor-egentlig (date of access: 15.06.2018).

$D D O$ - Den danske ordbog. Modern dansk sprog // Det Danske Sprog- og Litteraturselskab. URL: http://www.ordnet.dk/ddo (date of access: 22.05.2018).

$D K$ - Dansk Kvindesamfund. Kvinden og samfundet, vinter 2012. URL: https://danskkvindesamfund. $\mathrm{dk} / \mathrm{wp} . . . / \mathrm{ksvinter2012.pdf}$ (date of access: 22.05.2018).

\section{REFERENCES}

Andreyanova M.A., 2011. Realization of the Concept 'Mother' (Mere) in the French and Russian Languages (Based on the Novels by E. Zola and L. Tolstoy). Vestnik Chelyabinskogo gosudarstvennogo universiteta [Bulletin of Chelyabinsk State University], no. 28 (243), pp. 13-16.

Andreyanova M.A., Bagautdinova G.A., 2011. Realization of the Concept 'Mother' in the Russian and English Languages (Based on the Novels by M. Gorky and J. E. Steinbeck). Vestnik Chelyabinskogo gosudarstvennogo universiteta [Bulletin of Chelyabinsk State University], no. 17 (232), pp. 17-22.

Ani Rakhmat, 2012. Verbalization of the Concept 'Mother' in Russian Phraseology (As Compared to Indonesian Language). Izvestiya Rossiyskogo gosudarstvennogo pedagogicheskogo universiteta im. A.I. Gertsena [Izvestia: Herzen University Journal of Humanities \& Science], no. 152, pp. 101-105.

Atroshchenko E.O., 2014. The Functioning of the Concept 'Mother' in the Russian Fiction of the $19^{\text {th }}$ Century. Nauchnyy zhurnal Kubanskogo gosudarstvennogo agrarnogo universiteta [Scientific Journal of KubSAU], no. 97, pp. 1-12.

Vasyagina N.N., 2013. Subjective Formation of Mother in the Russian Modern Socio-Cultural Field: Monograph. Ekaterinburg. 364 p.

Dyakieva B.B., Omakaeva E.U., 2012. The Image of Mother in Kalmyk Folklore: Towards the Problem of Universal and Specific (Based on the Material of Folklore Texts). Vestnik Kalmytskogo instituta gumanitarnykh issledovaniy, no. 2 , pp. 183-187.

Karelova I.I., 2008. The Concept 'Mother' in L.E. Ulitskaya Conceptual Sphere. Izvestiya Volgogradskogo gosudarstvennogo pedagogicheskogo universiteta [Ivzestia of the Volgograd State Pedagogical University], no. 10, pp. 18-21.

Matveeva E.V., 2004. The Analysis of Motherhood in the Light of Activities Theory. Kiev, VGGU Publ. 326 p. 
Miklyaeva A.V., Rumyantseva P.V., 2018. \#Sheisamother: Implicit Social Beliefs about Motherhood in the Modern Russian Internet Discourse. Zhenshchina $v$ rossiyskom obshchestve [Woman in Russian Society], no. 1 (86), pp. 67-77.

Perevalova S.G., 2016. Verbalization of the Concept 'Mother' through the Proverbal-Saying and Phraseological Funds of the Russian Language (As Compared to the French Language). Nauchnyy vestnik Voronezhskogo gosudarstvennogo arkhitekturno-stroitelnogo universiteta. Seriya: Lingvistika i mezhkulturnaya kommunikatsiya, no. 2 (21), pp. 135-139.

Popova Z.D., Sternin I.A., 2007. Cognitive Linguistics. Moscow, AST; Vostok-Zapad Publ. 314 p.

Sasunkevich O.M., 2009. Medicalization of Discourse about Motherhood in Belarus Media. Zhurnal issledovaniy sotsialnoy politiki [The Journal of Social Policy Studies], vol. 7, no. 3, pp. 405-418.

Svitich L.G., 2015. Family and the Future of Russia. Sociological Research: Content Analysis of Contest Publications. Moscow, Moscow State University Publ. 154 p.

Shpakovskaya L.L., 2014. Discourse Production of Social Disparity of Motherhood. Zhenshchina $v$ rossiyskom obshchestve [Woman in Russian Society], no. 2 (71), pp. 77-85.

Yusupova O.G., 2000. The Social Meaning of Motherhood in Modern Russia: ("No One Cares about Your Child Except You"). Sotsiologicheskie issledovaniya, no. 11, pp. 98-107.

Vaillancourt M.A., 2015. Mediated Motherhood: Discourse and Maternal Identity in the Digital Age. Dissertation. Paper 357. URL: https:// surface.syr.edu/cgi/viewcontent.cgi?referer= https:/www.google.ru/\&httpsredir=1\&article= 1357\&context $=$ etd (accessed 25 March 2018).

\section{SOURCES AND DICTIONARIES}

The Happiness of Being a Mother: Russia Celebrates Mother's Day“. Vesti.ru, 2016. URL: https:// www.vesti.ru/doc.html?id=2826437 (accessed 15 June 2018).

“The Mother's Glory Campaign Has Been Launched in Lipetsk". Vesti.ru, 2017. URL: https://www. vesti.ru/doc.html?id=2929087 (accessed 15 June 2018).

“Anna Kuznetsova: Motherhood Has Its Special Mission". Vesti.ru, 2018. URL: https:/www. vesti.ru/doc.html?id=2993884 (accessed 15 June 2018).

"Career-mother. Children or Work, It's Not a Right Choice?". Rossiyskaya gazeta, 2013, no. 220. URL: https://rg.ru/2013/10/02/kariera.htm (accessed 15 June 2018).

"Mother Can. When a Family with Many Children Will Be in Mainstream?" Rossiyskaya gazeta, 2017, no. 273. URL: https://rg.ru/2017/11/30/ kogda-v-rossii-vojdut-v-modu-mnogodetnyesemi.html (accessed 15 June 2018).

"Hvad er en 'rigtig' mor egentlig?". Berlingske, 28 September 2016. URL: https:/www.b.dk/ nationalt/hvad-er-en-rigtig-mor-egentlig (accessed 15 June 2018).

“Jeg elsker ikke at være mor”. Berlingske, 29 September 2016. URL: https://www.b.dk/ nationalt/hvad-er-en-rigtig-mor-egentlig (accessed 15 June 2018).

Den danske ordbog. Modern dansk sprog. Det Danske Sprog-og Litteraturselskab. URL: http:// www.ordnet.dk/ddo (accessed 22 May 2018).

Dansk Kvindesamfund. Kvinden og samfundet, 2012. URL: https://danskkvindesamfund.dk/wp.../ ksvinter2012.pdf(accessed 22 May 2018).

\section{Information about the Authors}

Anna A. Kuvychko, Candidate for a Degree, Department of Russian Literature and Intercultural Communication, Pushkin State Russian Language Institute, Akademika Volgina St., 6, 117485 Moscow, Russia, anna_kuvychko@bk.ru, https://orcid.org/0000-0002-4303-5487

Albertina G. Chafonova, Lecturer, Department of Russian as a Foreign Language, Pushkin State Russian Language Institute, Akademika Volgina St., 6, 117485 Moscow, Russia, porijoki@nextmail.ru, https://orcid.org/0000-0003-3480-4798

Vera V. Boguslavskaya, Doctor of Sciences (Philology), Associate Professor, Professor of Department of Russian Literature and Intercultural Communication, Pushkin State Russian Language Institute, Akademika Volgina St., 6, 117485 Moscow, Russia, boguslavskaya@gmail.com, https://orcid.org/ 0000-0003-4118-382X 


\section{Информация об авторах}

Анна Александровна Кувычко, соискатель кафедры русской словесности и межкультурной коммуникации, Государственный институт русского языка им. А.С. Пушкина, ул. Академика Волгина, 6, 117485 г. Москва, Россия, anna_kuvychko@bk.ru, https://orcid.org/0000-0002-4303-5487

Альбертина Германовна Чафонова, преподаватель кафедры русского языка как иностранного, Государственный институт русского языка им. А.С. Пушкина, ул. Академика Волгина, 6, 117485 г. Москва, Россия, porijoki@nextmail.ru, https://orcid.org/0000-0003-3480-4798

Вера Васильевна Богуславская, доктор филологических наук, доцент, профессор кафедры русской словесности и межкультурной коммуникации, Государственный институт русского языка им. А.С. Пушкина, ул. Академика Волгина, 6, 117485 г. Москва, Россия, boguslavskaya@gmail.com, https://orcid.org/0000-0003-4118-382X 